\title{
Impact of Customer Based Brand Equity (CBBE) on Customer Retention: A comparative study of Government, Private and Foreign banks of Lahore, Pakistan
}

\author{
Shoaib Tahir \\ Institute of Professional Development, Lahore \\ Dr. Faisal Aftab \\ Director Research: Bahria University, Islamabad \\ Rab Nawaz Lodhi \\ Institute of Business and Management \\ University of Engineering\& technology, Lahore
}

\begin{abstract}
Purpose: This paper has drawn the attention to study the customer based brand equity in service sector especially in banking sector of Pakistan. The rationale of this study is to explore any relationship between different dimensions of CBBE and customer retention.

Methodology/Sampling: This study has been conducted in Lahore. Convenience sample of 300 respondents has been used for data collection. The results have been established by using quantitative and qualitative techniques. Survey method was adopted to collect quantitative data through questionnaires and interviews have been conducted to collect the qualitative data through audio recorded interviews. SPSS has been utilized for quantitative data analysis and NVivo 10 has been used for qualitative data analysis.

Findings: The study found that perceived quality and organizational association have significant positive relationship with customer retention. Further this study has determined the difference in CBBE among foreign, private and government banks and found the CBBE is highest in foreign banks.

Practical Implications: The findings of the study is beneficial for the Government, Private and Foreign Banks to retain their customers through consumer based brand equity.
\end{abstract}

Keywords: Perceived Quality, Brand Image, Brand Association, Brand loyalty and Customer Retention.

JEL Classification: C21, M21, M31.

* The material presented by the authors does not necessarily portray the viewpoint of the editors and the management of the Institute of Business \& Technology (IBT).

*Shoaib Tahir: mian.shoaib@live.com

* Dr. Faisal Aftab: faftab@bahria.edu.pk

* Rab Nawaz Lodhi

CJMSS is published by the Institute of Business and Technology (IBT). Main Ibrahim Hydri Road, Korangi Creek, Karachi-75190, Pakistan. 


\section{INTRODUCTION}

The roots of Banking can be traced by the Jewish society. They were used to practice the banking activities in very large and extremely open markets. With the passage of time the banking activities gain much popularity and finally an institution came into existence named as "Bank". Almost in every country the banks were divided into two forms either state owned or privately owned.

In current age of globalization, along with consumer product markets, several service markets have also started to operate across the globe. In the last decade introduction of e-commerce, development of internet banking, introduction of mobile banking and overall effect of globalization on all these factors has integrated the financial markets and encouraged a healthy competitive environment among the financial institutions (Neillis et al, 2000). To meet the challenges of such competitive markets and to become a global player the banks now pursuing a uniform branding strategy for all, new and existing markets. (Neillis et al, 2000 ; Robinson, 2007). Fairland (1995) established that the opportunities for banks to grow in the new and promising markets can only be captured by adopting global branding strategies. Robinson (2007) while explaining the global branding in banking industry asserted that banks can only reap the fruits of global branding if there is a consistency between the experience of customers and the brand of bank. Perceived service quality is the most important dimension of Branding strategy and effective branding helps to ensure the customer, a uniform service quality (Berry, 2000).

Now many banks are working in different countries by adopting international and uniform branding strategies. In some cases these banks face a high degree of confrontations against the local banks of the new market only due to the perceived service quality and organizational association of the local people with the local brands. Eser et al. (2006) concluded with the same results thatcustomer service quality in different banks (state, private and foreign) is different in the same country and same market. Pinar and Eser(2008) conducted another research and found that the service quality perceived by the personnel of the different banks (state, private and foreigner) is different at the same point of time even at the same geographic location. Pinar, Girrard and Eser (2012) found in their research, another challenge that is the association of the local customers with their national brands. Due to this association the multinational banks get only a small proportion of the potential customers.

Researchers in the past paid much attention on the branding strategies for consumer products but unfortunately, the branding strategies for service market gained very less consideration. Theliterature confirms that there is a little work that has been done to investigate the relationship of consumer based brand equity and service quality of any service oriented firm (He and $\mathrm{Li}, 2011$ ). Further there is a very limited research available that finds the relationship of effective brand equity with customer retention in the banking industry of Pakistan. As service sector holds a major and growing share in the GNP of Pakistan and in service sector financial services holds a sizable contribution. According to (State Bank Of Pakistan, 2012) there are nine Government banks with 2559 branches, 22 private banks with 8354 branches and seven foreigner banks with 27 branches giving a total of 38 banks operating in Pakistan with 10940 nationwide branches. 
So there is a need for the banking industry of Pakistan to find the differences of customer based brand equity among private, government and foreign banks and then implement the effective branding strategy in the highly diverse and competitive environment. This study is intended to fill this gap by accomplishing following research objectives.

Research objectives are actually the purpose of the study. This study has following objectives to be accomplished.

1. To explore any difference in the dimensions $\mathrm{CBBE}$ in private, government and foreign banks.

2. To explore the relationship of these dimensions with customer retention.

This study has following questions to determine.

1. Is there any difference in the dimensions of consumer based brand equity in the Government, private and foreigner banks of Pakistan?

2. If there is any difference in CBBE then which type of bank holds most strong brand equity?

3. What is the relationship of different dimensions of CBBE with the customer retention in the banking industry?

The outcome of this study will facilitate the brand managers of the government and private banks of Pakistan to develop effective branding strategies while encountering their global foreign competitors in their country. This study will also contribute in the knowledge as it will explore the relationship of customer retention with the different dimensions of $\mathrm{CBBE}$ in banking industry which was previously ignored by most of the researchers.

\section{LITERATURE REVIEW}

Kotler (1991, p.442) defines brands as "a name, term, sign, symbol, or design, or combination of them which is intended to identify the goods and services of one seller or group of sellers and to differentiate them from those of competitors". Brand management is very essential activity of marketing department of any organization because if brands are managed successfully and efficiently, a firm can get competitive advantage in the market (Aaker, 1989).

In the past literature brand equity has been explained and described in many ways by different authors but the most acceptable and simple definition is given by (Farquhar 1989, p. 47) that "Brand equity is the added value endowed by the brand to the product." Literature further enlightens that there are two core viewpoints in which brand equity can be studied, firm based brand equity and consumer based brand equity. Firm based brand equity is measured in financial return terms and focused on that part of value that a brand adds to the firm (Simon and Sullivan, 1993; Mahajan et al, 1990). The other perspective is consumer based brand equity that focuses on the value added by a specific brand to the consumers (Aaker, 1991; Keller, 1993 and Rangaswami et al. 1993). 
Although there are number of explanations regarding consumer based brand equity but according to (Park and Sirinivasan, 1994) in literature this is not any single agreed upon definition and explanation. For example (Keller, 1993, p. 8) explain consumer based brand equity in terms of only two dimensions brand knowledge and brand image but (Aaker, 1991) explained it in terms of four important dimensions, brand awareness, brand loyalty, brand association and perceived quality. Yoo et al. (2000) conducted a research and adopted confirmatory factor analysis technique to limit the dimensions of CBBE up to only three dimensions by combining two major dimensions brand association and brand awareness.

Papu, Quester and Cooksay(2005) opposed and challenged the results of the study of (Yoo et al, 2000) and again established in their study that brand association andbrand awareness are different and distinct dimensions of CBBE. Along with four conventional dimensions, Kim and Kim (2004) and Buil et al. (2008) added two additional dimensions, organizational association and brand personality, in the consumer based brand equity model. Pinar, Girard and Eser (2012), incorrigibly used six dimensions of CBBE while examining the banking industry of Turkey. These dimensions are Brand awareness, perceived quality, brand image, brand loyalty, brand association, organizational association and.

Harams (2002) categorized service industry into two types. First those services which have no link with any physical product at any stage and secondly those services which ultimately have a link with a physical product. Bamert and Wehrli (2005) described many properties of the services that differentiate them from physical goods. Like services are intangible but one can feel tough, taste or even see the goods unlike services. Further, goods are usually uniform in nature but services are most of the time heterogeneous in quality. This element of heterogeneity in quality of service posed many difficulties and challenges for the service industry. According to (Berry, 1986, p.6 and Levitt, 1981, P. 101) the success in the service industry can be achieved by converting intangible services into tangible services. Though this is a very difficult task but this can be done through branding.

In financial service markets the nature and types of products demanded by consumers and supplied by banks have changed dramatically due to advanced technology and deregularization (Harris, 2002). In such dynamic and technological arena there is a controversy in literature that whether the branding strategies of the consumer goods markets applicable in financial service markets (Camp 1996, 1999).

Miao Mackay (2001) suggested that we can use all dimensions of CBBE related to consumer goods market, in the service markets. In the context of service industry literature further divides brand equity of service industry in functional elements (related to tangible characteristics) and emotional elements (related to intangible characteristics).Further (de Chernatony and Dall 'Olmo Rilay,1999 ; Palmer, 2001) concluded that the emotional element of the brand equity is more important to the customer of financial institutions rather than functional elements and suggested that in financial service industry the brand differentiation can be ensured by introducing some unique emotional values. But (Loughlin and Szimigin, 2004) studied Irish bank industry and established the entirely opposite fact that customers consider functional values more than that of emotional values of brand equity and service quality is a significant dimension of functional value of brand equity. 
The banking industry in Pakistan is very diverse in nature and rich in competition as there are a variety of financial services that are being offered by a number of financial institutions. In such competitive environment there is a high probability that the consumer will switch to the service provider who will offer more favorable services. Miles (2004) and Mintel (2002a) confirmed this reality while examining the consumers in UK bank industry.

While explaining the major reasons, why customers switch from one brand to other literature divides them in three categories. The first category is push away and in this category the brand loses the customers due to negative qualities of the brand (Bansal et al., 2005). The second category is pull away. In this category the customers switch to other brands due to the positive attributes of the other brands. In such cases the customers have less focus on the negative attributes of the brands they currently use (Bansal et al., 2005). The last category is called move away. In this case the reasons of customer switching is out of the control of brand managers. Consumers neither center on the negative attributes of his brand nor focus on the positive qualities of the competitors (Bansal et al., 2005).

\section{CONCEPTUAL FRAMEWORK}

The conceptual framework of the study has been explained in the Figure-1. Perceived Quality, Brand association, Brand image, Brand loyalty and Organizational Association are the independent variables while Customer Retention is dependent variable. This framework shows that there is a relationship between dependent variable (DV) and independent variables (IV).

Figure 1

Theoretical Framework

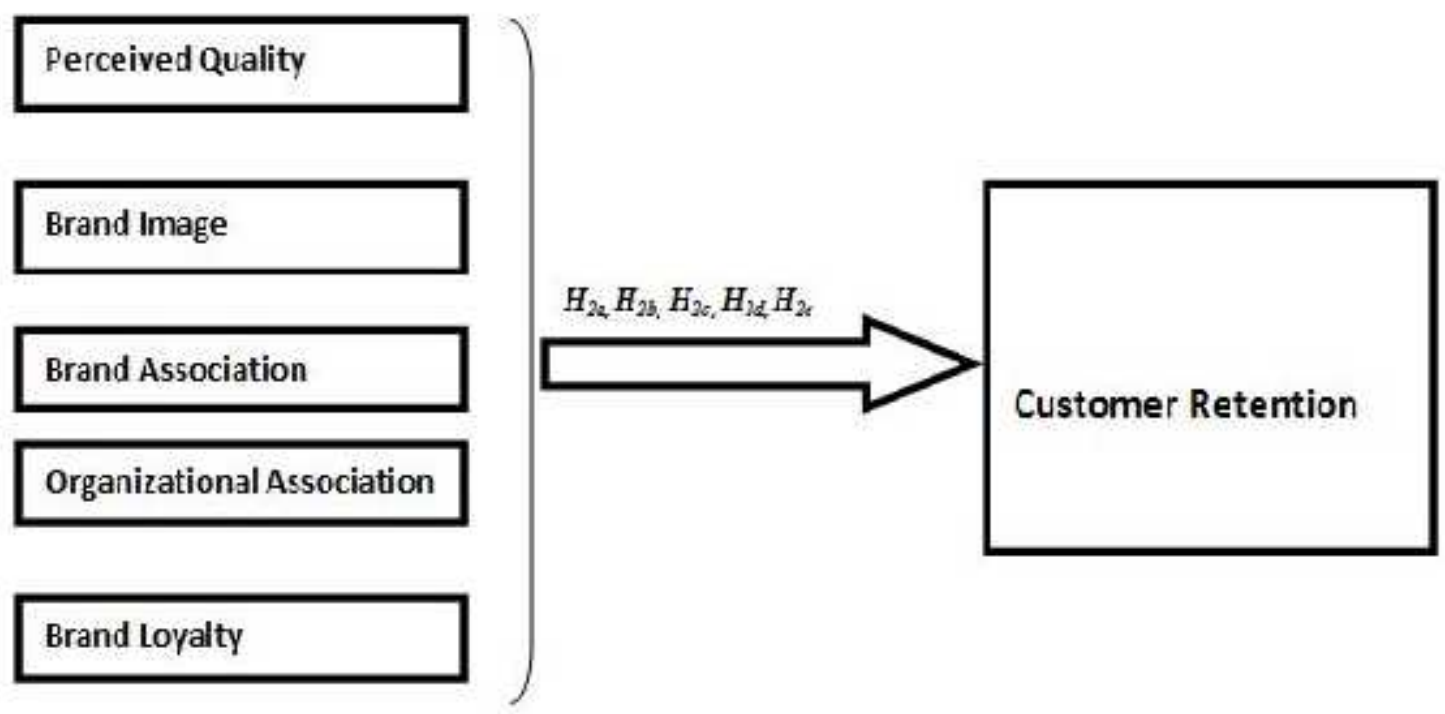




\subsection{Development of Hypothesis}

\subsubsection{Difference in Customer based Brand Equity in Private, Government and Foreigner Banks}

Eser et al. (2006) concluded that customer service quality in different banks (state, private and foreign) is different in the same country while conducting his study in Turkey. Pinar and Eser(2008) conducted another research in different context and found that the service quality perceived by the personnel of the different banks (state, private and foreigner) is different at the same point of time even at the same geographic location. Pinar, Girrard and Eser (2012) found in their research, another challenge that is the association of the local customers with their national brands which shows the organizational associational difference of the bank customers. On the basis of prior researches this study established the hypothesis.

$\boldsymbol{H}_{1}$ : There is a significant difference in dimensions of CBBE: ( $\left.H_{1 a}\right)$ perceived quality; $\left(H_{1 b}\right)$ brand image; $\left(H_{l c}\right)$ brand association; $\left(H_{l d}\right)$ organizational association; and $\left(H_{l f}\right)$ brand loyalty across all three types of the banks.

\subsubsection{CBBE and customer retention}

To overcome the switching behaviors of the customers financial institutions are not only interested to acquire new customers but also taking care of the value and benefits that can be achieved by retaining the existing customers (Farquhar and Panther 2008). Stahl et al. (2012) studied US car industry to find the relationship of brand equity with customer acquisition and customer retention and concluded that brand equity has a significant relationship with customer acquisition and retention. Farquhar and Panther (2008), conducted an exploratory study in banking industry of UK and concluded that Brand knowledge and brand loyalty can be of significant worth, while acquiring the new customers and retaining the existing customers. If the brand managers uncover the reasons of customer defection this will be very helpful for them to improve the retention rate of their customers. As the prior studies found the relationship of customer retention with limited dimensions of consumer based brand equity. This study is intended to find the relationship of customer retention with all dimensions of consumer based brand equity and proposed following hypothesis in this regard.

$\boldsymbol{H}_{2}:$ There is a significant relationship between customer retention and CBBE: $\left(H_{2 a}\right)$ perceived quality; $\left(H_{2 b}\right)$ brand image; $\left(H_{2 c}\right)$ brand association; $\left(H_{2 d}\right)$ organizational association; and ( $\left.H_{2 f}\right)$ brand loyalty.

\section{METHODOLOGY}

\subsection{Research Design}

As the objectives of the study are very broad and the study is exploratory and explanatory in nature that is why the mixed methodology has been used. Positivistic paradigm has been followed by using quantitative techniques (i.e. survey method) to find the difference of consumer based brand equity among three types of banks in Pakistan and to find the impact of customer based brand equity on customer retention. Phenomenological paradigm has been 
Impact of Customer Based Brand Equity (CBBE) on Customer Retention: A comparative study of Government, Private and Foreign banks of Lahore, Pakistan

adopted by using qualitative techniques (i.e. interview method) to explore the factors affecting the customer retention in banking industry.

\subsection{Target Population}

All customers of local private, government and private foreign banks in Lahore are the target population for this study. All customers of the Islamic banks have been excluded from the target population as this study has been conducted only on the consumers of the conventional banks.

\subsection{Sampling Technique}

A convenience sampling technique has been adopted for this study as the size of the target population is unknown.

\subsection{Sample size}

Lahore the second largest city of the Pakistan with population over seven millions was selected for the data collection. After examination of the returned questionnaires and eradication of unfeasible ones, there were a total of 300 questionnaires available for analysis. Out of these 300 questionnaires 105 were of the customers of Government banks, 100 of Private banks and 95 of Foreign banks.

To collect the qualitative data 15 interviews were conducted. These interviews were taken from those customers of the banks who retained with their banks for at least 6 years. 5 Respondents were doing jobs the Government sector organizations, seven were doing jobs in private sector organizations and three respondents were businessmen.

\subsection{Time horizon}

There are two types of studies with respect to the time horizon. Longitudinal and cross sectional studies. This paper is a cross sectional study due to the time constraint and the data has been collected at one point of time through questionnaire and interviews.

\subsection{Measurement of Variables}

The instrument of survey is used in this study to achieve the objectives and to measure the customer based brand equity. A self-administer questionnaire was used to collect the data. The first section of the questionnaire consisted of the demographic information of the respondents like their gender, age and the type of their bank. In the second section, dimensions of the customer based brand equity have been divided into multiple-item scales after exploring the literature. Perceived quality was measured by four items that were common in (Builet al., 2008; Kim and Kim, 2004; Yoo and Donthu, 2001; Yoo et al., 2000; Aaker, 1991, 1996a). The brand image was measured by four items adapted from (Kim and Kim, 2004). Organizational association was measured by three items developed from (Pinar, Girard and Eser, 2012). Brand loyalty was measured by four items developed from (Kim and Kim, 2004; Pinar, Girard and 
Eser, 2012 and Builet al., 2008). Brand association was measured by three items derived from (Pinar, Girard and Eser, 2012). Customer retention was measured by seven items derived from (Bogomolova, 2010 and Bansal et al. 2005). All the variables except brand awareness were measured on five point Likert-scale ranging from 1 strongly disagree to 5 strongly Agree. The questionnaire also includes demographic questions regarding gender, age, source of income and bank type. Brand awareness was measured by the top of the mind recall method proposed by (Aaker, 1996a; Builet al. 2008; Pappu et al. 2005 and Yoo et al. 2000).

For a detailed analysis this study is intended to use following five dimensions while measuring consumer based brand equity.

\subsubsection{Perceived quality}

Perceived quality is the perception and insight of the customer on which they evaluate the products or service. In service sector through perceived quality customers differentiate the different services (Aaker, 1991).

\subsubsection{Brand loyalty}

Brand loyalty is the behavioral dimension of brand equity and it is a degree to which a consumer is attached with a brand. When a customer buys a brand as a first choice then this customer is brand loyal customer (Aaker, 1991, p.39; Yoo and Donthu, 2001, p.3).

\subsubsection{Brand association}

Aaker (1991 p.109) defined brand association as "any link in the memory to the brand" and brand image as "set of brand associations"

\subsection{Quantitative Data Analysis}

The 16.0 version of SPSS is utilized for data analysis. Factor analysis has been performed and Cronbach Alpha showed the reliability of data and validity of the constructs and questions. Analysis of variance (ANOVA) has been run to test the differential hypothesis of the study. Regression analysis has been conducted to test the relationship and impact of IV's on the DV.

\subsection{Qualitative Data Analysis}

For qualitative data analysis NVivo 10 has been used. An audio interview was conducted initially in Urdu Language as it is the native language of Lahore. Then these recorded interviews were translated and converted in English for further analysis. Firstly, of all the audio recorded interviews of the respondents were transcribed into the textual form. After transcribing the data thematic, frequency and cluster analysis are carried out with the help of NVivo. Different nodes were created and similar themes were added in the same nodes. 
Impact of Customer Based Brand Equity (CBBE) on Customer Retention: A comparative study of Government, Private and Foreign banks of Lahore, Pakistan

\section{RESULTS AND FINDINGS}

Table 1 shows that all the variables such as brand image, perceived quality, organizational association, brand loyalty, brand association and customer retention have reasonable reliability with Cronbach Alpha $>0.70$.

Table 1

Cronbach Alpha

\begin{tabular}{|l|c|}
\multicolumn{1}{|c|}{ Vorlabin } & $\begin{array}{c}\text { Cronhach } \\
\text { Alpha }\end{array}$ \\
\hline Perceived Quality & 0.912 \\
\hline Bidrulindge & 0.930 \\
\hline Brand Association & 0.918 \\
\hline Urganizationalnssociation & 0.901 \\
\hline Brand Loyalty & 0.911 \\
\hline Customerretention & 0.526 \\
\hline
\end{tabular}

\subsection{Testing Hypothesis $\mathrm{H}_{1 \mathrm{a}}-\mathrm{H}_{1 \mathrm{e}}$}

To test hypothesis the analysis of variance (ANOVA) using post hoc procedure was adopted. Table- 2 shows the results of this analysis. Pair wise comparisons of perceived quality shows that there is a significant difference between private and government banks, private and foreigner banks, government and foreigner banks as $p<(.05)$. Results further shows that the customers of foreign banks have the highest perceived quality and the government banks have lowest perceived quality as the $\mathrm{F}$ value for foreigner banks was highest while measuring perceived quality.

Table 2

ANOVA

\begin{tabular}{|c|c|c|c|c|}
\hline \multirow{2}{*}{ 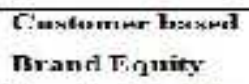 } & \multirow[b]{2}{*}{ Bank A } & \multirow[b]{2}{*}{ Ranls B } & Wman Diftremacia & \multirow[b]{2}{*}{ Signifiranre } \\
\hline & & & (Tiank A Ranle $\mathbf{B}$ ) & \\
\hline \multirow[t]{2}{*}{ Felceived Quality. } & Foceigne: & Privale & 0.18 & 0.002 \\
\hline & & Guvernimeil & 1.16 & 0.0001 \\
\hline \multirow[t]{2}{*}{ Hrand mare } & Forcipmer & irivate & o.s. & (x) 1212 \\
\hline & & C:sv:mment & 1.9 & $0: 00+1$ \\
\hline \multirow[t]{2}{*}{ Brand $\Delta s$ sediatios } & roreiguer & Private & 0.56 & 0.001 \\
\hline & & Citovernotent & 021 & 0.0001 \\
\hline \multicolumn{5}{|l|}{ 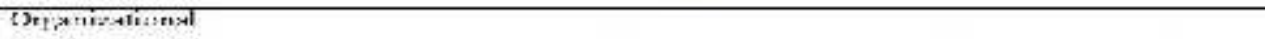 } \\
\hline \multirow[t]{3}{*}{ Ascociation } & Toreigues & Private & 0.55 & 0.0001 \\
\hline & & Govemumeat & 0.9 & 0.2001 \\
\hline & Govermment: & Private & 0.21 & $x=0.131$ \\
\hline \multirow[t]{2}{*}{ Biand Luratir } & Forcipues & Privati & 0.45 & 0.008 \\
\hline & & ctovemine & 711 & $0: 10001$ \\
\hline
\end{tabular}

Therefore $\boldsymbol{H}_{1 \boldsymbol{a}}$ was accepted. As for brand image there were significant differences between government and private, private and foreign, private and foreign banks as $p<(.05)$ for all the 
differences. Further it was found the brand image for customers of foreign banks was higher than private and government banks. Hence $\boldsymbol{H}_{\boldsymbol{l}}$ was accepted. There was a significant difference of brand association between private and government, private and foreign, foreign and government banks as $p<(.05)$. For brand association foreign banks had highest F-value and government banks had lowest. This showed that the customers of foreign banks have highest brand association. Therefore $\boldsymbol{H}_{1 \boldsymbol{c}}$ is accepted. Concerning organizational association there was a significant difference between government and foreign banks and private and foreign banks as $p<(.05)$ but there was no difference between private and government banks as $p>(.05)$. F-value showed that organizational association was highest for foreign banks. Therefore $\boldsymbol{H}_{\boldsymbol{l} \boldsymbol{d}}$ is partially accepted. The finding of the study further proved that there was also a significant difference of brand loyalty among private, government and foreign banks. And the customers of foreign banks have highest brand loyalty and the customers of foreign banks were more loyal than that of private and government banks. Therefore $\boldsymbol{H}_{\boldsymbol{l} \boldsymbol{e}}$ is accepted. Over all $\boldsymbol{H} \boldsymbol{1}$ is partially accepted.

\subsection{Testing Hypothesis $\mathrm{H}_{2} \mathrm{a}-\mathrm{H}_{2} \mathrm{e}$}

Table-3 gives an idea about the results of the multiple linear regressions applied to test any impact of dependent variables on the dependent variable.

R-Squared $\left(\mathrm{R}^{2}\right)$ was 0.23 which indicates that $23 \%$ change was occurred in the dependent variable due to given five independent variables brand association, brand image, perceived quality, brand loyalty and organizational association. The remaining $63 \%$ changes took place due to some additional factors that were out of the scope of this study. The F-statistic is 14.548 which should be greater than 5 and the $\mathrm{P}$-value $=.0001$ which shows significant relationship between dependent and independent variables (as $\mathrm{p}<0.05$ ). With more result and analysis of the regression some hypotheses have been accepted and some rejected.

The analysis between perceived quality and customer retention in Table- 2 shows that there is a significant relationship between perceived quality as independent variable and customer retention as dependent variable with t-statistic value is 2.071 and $p<0.05$, the value of coefficient was 1.85. In this way $\boldsymbol{H} \mathbf{2} \boldsymbol{a}$ has been accepted. According to Table II further analysis of the brand image as independent variable and customer retention as dependent variable shows that there is no significant relationship between brand image and customer retention as tstatistic is $0.921, \mathrm{p}>0.05$ with coefficient value 0.077 . According to the findings $\boldsymbol{H} \boldsymbol{2} \boldsymbol{b}$ was rejected. The findings also revealed that there is no significant relationship between brand association and customer retention as coefficient value is 0.015 , t-statistic is 0.253 and $\mathrm{p}>0.05$. Thus according to the finding $\boldsymbol{H} \mathbf{2} \boldsymbol{c}$ was rejected. The analysis also explained that there is a significant relationship between organizational association and customer retention with beta coefficient 0.367 . While the $\mathrm{p}$ is $0.0001<0.05$ accepting $\boldsymbol{H 2 d}$. According to the findings of the study there was no significant relationship between brand loyalty and customer retention as the t-statistic value was $0.007, \mathrm{p}>0.05$ and the value of coefficient was 0.091 . So $\boldsymbol{H} 2 \boldsymbol{e}$ was also rejected. This study has partially achieved its objectives. From the above results $\boldsymbol{H} \boldsymbol{2}$ has been partially accepted.

Results of multiple linear regression suggested that perceived quality and organizational association have a positive relationship with customer retention. It means that when there will 
Impact of Customer Based Brand Equity (CBBE) on Customer Retention: A comparative study of Government, Private and Foreign banks of Lahore, Pakistan

be an increase in perceived quality and organizational association there would be an increase in customer retention.

Table 3

Multiple Linear Regression

\begin{tabular}{|c|c|c|c|}
\hline \multicolumn{2}{|l|}{ R-squared $=0.23$} & \multicolumn{2}{|c|}{ F-statistic $=14.548$} \\
\hline Variable & Coefficient & t-Statistics & Prob \\
\hline Perceived Quality & 0.185 & 2.071 & 0.039 \\
\hline Drand Image & 0.077 & 0.921 & 0.358 \\
\hline Brand Assuciation & 0.013 & -0.203 & 0.801 \\
\hline $\begin{array}{l}\text { Crganivalionial } \\
\text { Assoncintion }\end{array}$ & (1) 301 & 1091 & $(2): 51$ \\
\hline Brand Toyalty & $0 \mathrm{cos}$ & c) $(3 \rightarrow 1$ & $09 x$ \\
\hline
\end{tabular}

\subsection{Qualitative Analysis}

To explore the factors affecting customer retention number of techniques have been used in NVivo 10. It included transcription of audio recorded interviews, coding of data, cluster analysis, thematic analysis and word frequency analysis.

\subsection{Word Tree Analysis}

Retention is the key and main word. The option of text search query, in NVivo has been used to explore a word tree for the word "retention". Figure-II explains the different pattern of talks with respect to "retention" by reading each line of the responses.

Figure 2

Word Tree for word "Retention"

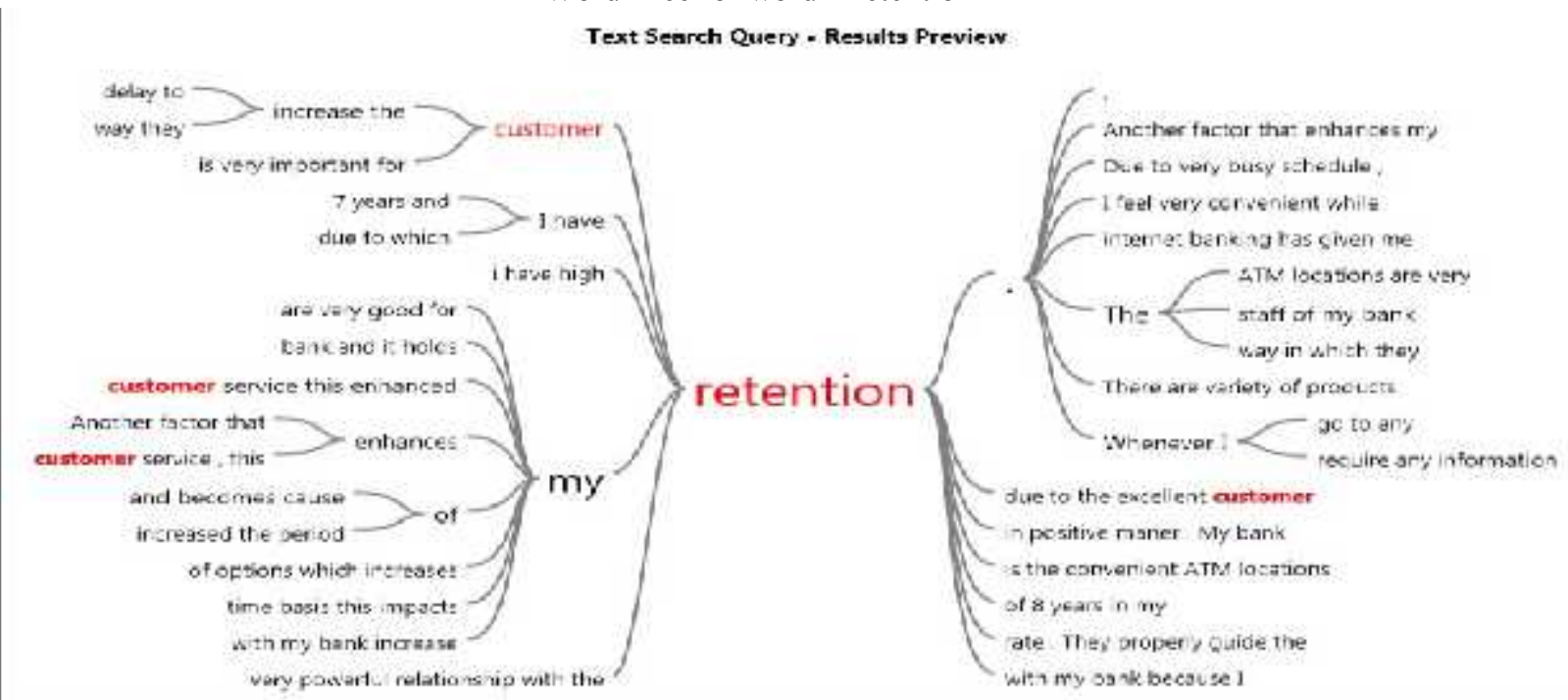




\subsection{Word Tag Cloud}

The frequencies and repetitions of different words used in the transcribed textual data have been analyzed by using word tag cloud as shown in Figure-III. Size of the word shows frequency and importance of that word in the study. Some important and frequently used words were convenient, courteous, customer, service, staff, sitting, ATM, interest etc.

Figure 3

Word Cloud

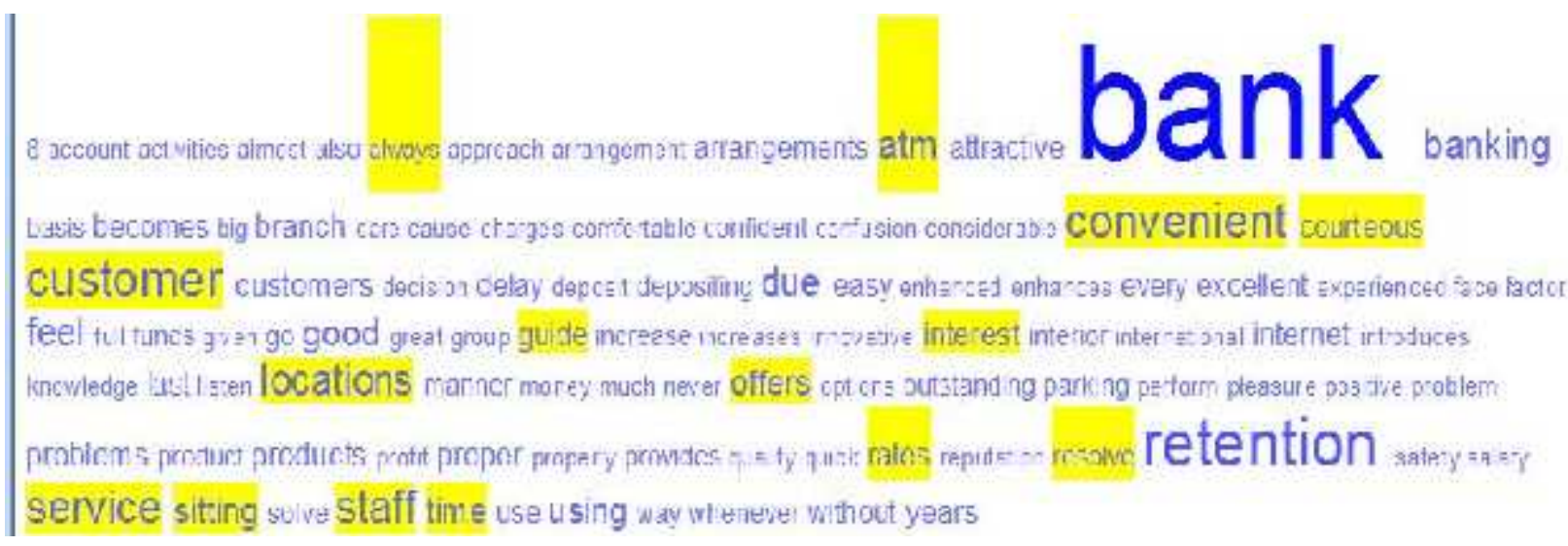

\subsection{Word tree Map}

After finding different important themes, the extent of relationship between central theme (Customer Retention) and other themes has been established by using Tree Map as shown in Figure-IV. According to the results of the map customer service is most influential factor for customer retention. Other important factors are interest rates, ATM location, and bank reputation. Some other factors have also been identified in the word tree map as shown in Figure 4. 
Impact of Customer Based Brand Equity (CBBE) on Customer Retention: A comparative study of Government, Private and Foreign banks of Lahore, Pakistan

Figure 4

Word Tree Map

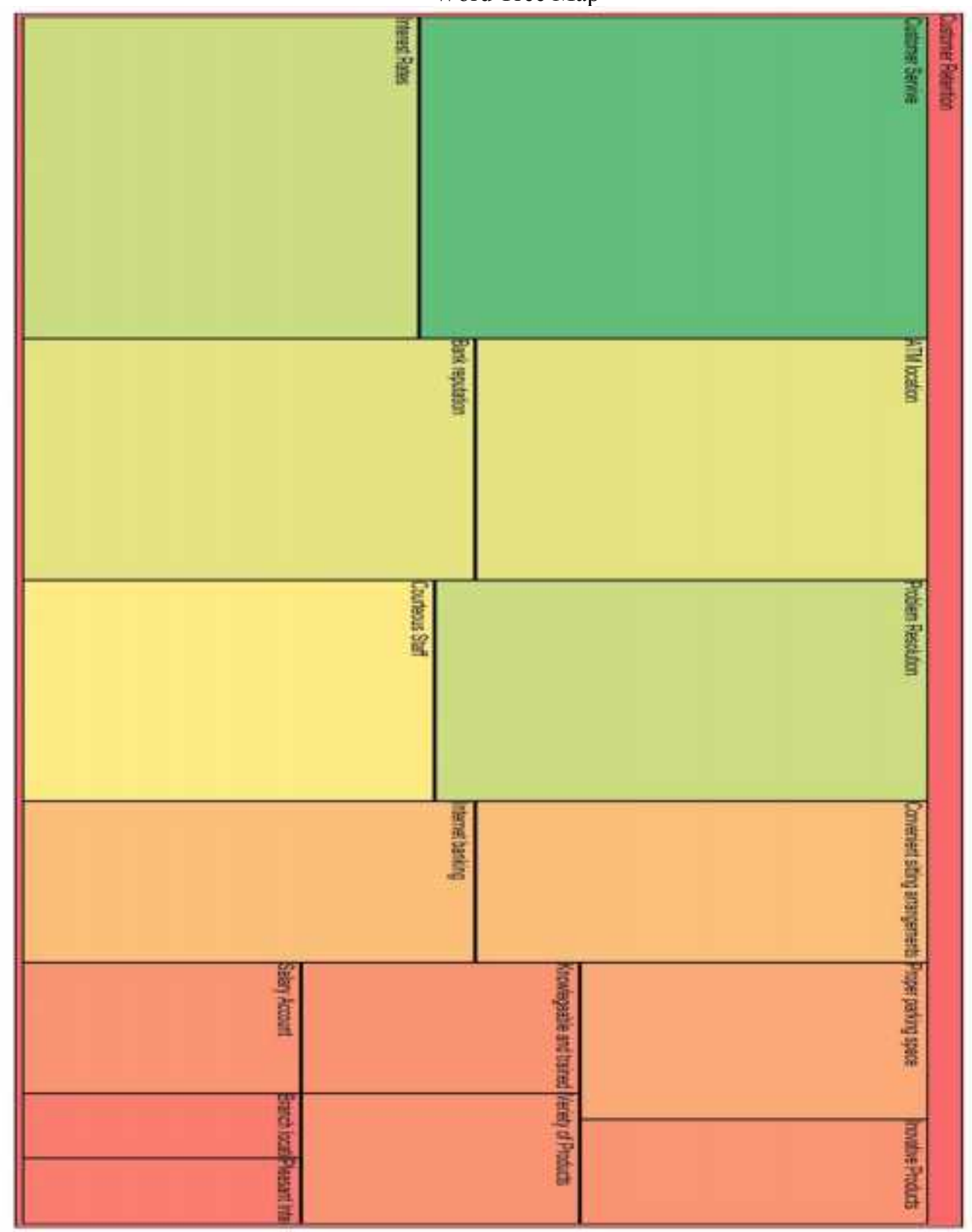

\subsection{Model of Themes}

Figure 5 shows the model of themes drawn by using Model option in NVivo. This is the model that explains the relation of parent node with the child nodes. Parent node is the central theme of the study that is Customer Retention and child nodes are all factors that influence the parent node or central theme. 
Figure 5

Model of the Themes

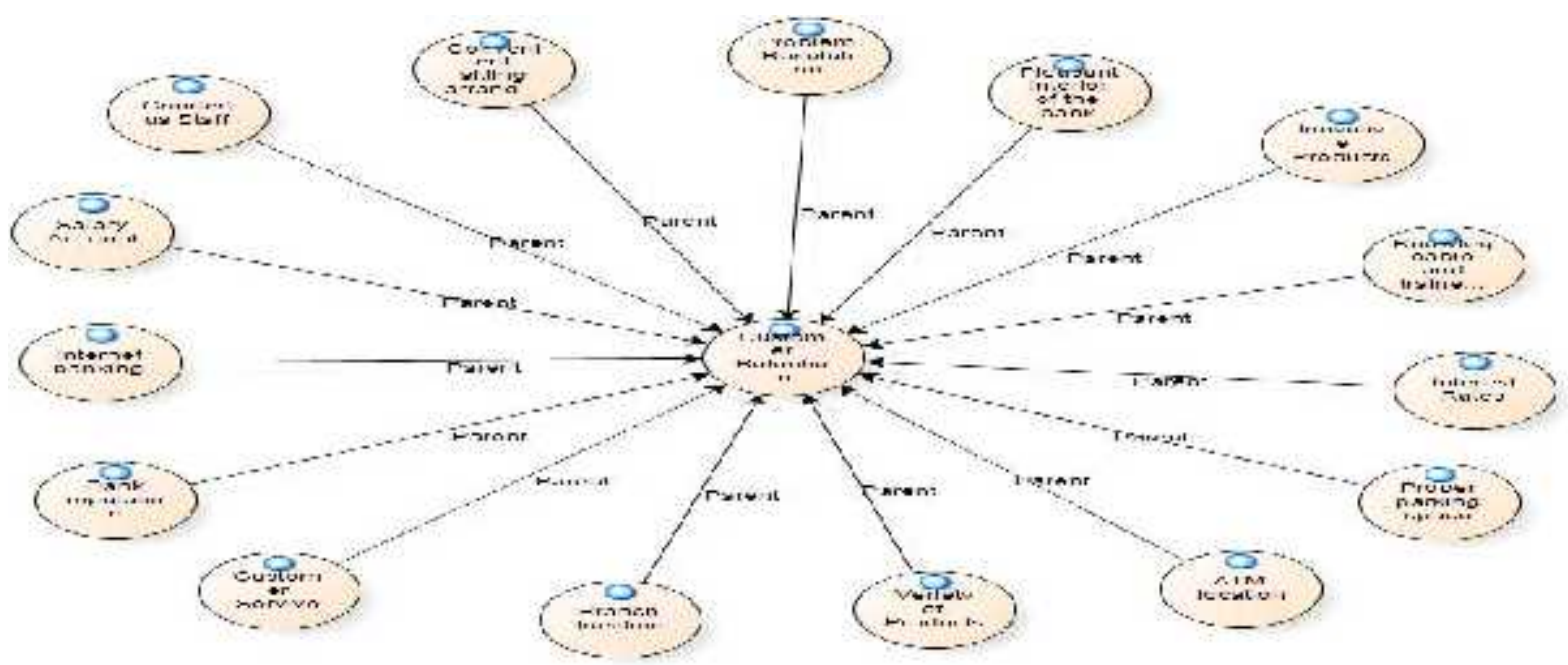

\section{CONCLUSION AND DISCUSSION}

The intention of this study was to find any difference between dimensions of CBBE and to find the relationship of these dimensions (as independent variable) with customer retention (as dependent variable), by using mixed methodology. The customers of private, government and foreign banks have been selected to gather the data. The quantitative data collection is done through questionnaire and qualitatively through audio recorded interviews. SPSS has been used for quantitative data analysis and NVivo has been used for qualitative data analysis. After analyzing the data it has been established that there was a difference in dimensions of CBBE among private, government and foreign banks in Pakistan. Foreign banks were at the top in every dimension of CBBE. Further it was also identified in the data analysis that there was a significant relationship between perceived quality, organizational association as independent variables and customer retention as dependent variable. No significant relation was found between other independent variables (brand loyalty, brand association andbrand image) and dependent variable (customer retention).

These results were confirmed by the qualitative data analysis. During qualitative data analysis it was found that customer service, problem resolution and bank reputation were the most influential factors affecting customer retention. Other important factors that affect customer retention were convenient ATM locations, attractive interest rates, convenient sitting arrangements, trained and courteous staff.

This study also filled the gap on the literature as previously no study has been conducted to find the relationship between CBBE and customer retention.

\section{GENERAL RECOMMENDATIONS}

On the basis of results this study proposes following recommendations 
- As foreign banks have highest customer based brand equity, the local private and government banks should restructure their branding strategies to compete with their global competitors.

- To retain their customers, private and government banks should focus on those dimensions which have significant relationship with customer retention.

- While developing brand strategies these banks should have a more focus and attention on the perceived quality and organizational association as suggested by the results.

- Other factors that have been identified in this study through qualitative analysis, like convenient ATM locations, competitive interest rates, courteous and well trained staff members, convenient sitting and parking arrangements should also be included in the brand strategies.

\section{LIMITATION AND FUTURE RESEARCH}

Limitations exist in almost every study. Usually researchers while conducting a study face a number of troubles and issues. This study has also some limitations. Convenience sampling technique has been adopted. A small sample size has been used due to less available time. This study has been conducted only in Lahore due to budget and time constraints.

This study has examined the relationship between different CBBE dimensions and customer retention. In future studies researchers can find the relationship of CBBE on customer acquisition. Because customer acquisition is a vital part and objective of the brand management so it must be studied in relation with CBBE.

This study has been conducted in Lahore by using convenience sampling and small sample size, future studies can be conducted in more cities for more generalized results by using other sampling technique.

\section{REFERENCES}

Aaker, D.A. (1989), Managing assets and skills: the key to a sustainable competitive advantage, California Management Review, Vol. 31 No. 2, pp. 91-106.

Aaker, D.A. (1991), Managing Brand Equity, The Free Press, New York, NY.

Berry, L.L. (2000), Cultivating service brand equity, Journal of the Academy of Marketing Science, Vol.28, winter, pp.128-37.

Bogomolova, S. (2010), Life after death? Analyzing post-defection consumer brand equity,Journal of Business Research Vol.63 pp.1135-1141.

BansalHarvir S, Taylor Shirley F, St. James Yannik (2005), Migrating to new service providers:toward a unifying framework of consumers' switching behaviors. Journal of the Academy of Marketing Science, Vol. 28 pp.96-115.

Berry, L.L. (1986), Big ideas in services marketing, Journal of Services Marketing, Vol. 1 No. 1, pp. 5-9. 
Bamert, T. and Wehrli, P., H. (2005), Service quality as an important dimension of brand equity in Swiss service industries, Managing service quality, Vol. 15 No. 2, pp.132-141

Buil, I., de Chernatony, L. and Martinez, E. (2005), A cross cultural validation of consumer based brand equity scale, Journal of product and brand management, Vol. 17 No. 6, pp.384-392.

deChernatony, L. and Dall' Olmo Riley, F. (1999), Experts' views about defining service brands and the principles of services branding, Journal of Business Research, Vol. 46 No. 2,pp. 18192.

Eser, Z., Pinar, M., Birkan, I. and Crouch, H. (2006), Using mystery shoppers as a benchmarking tool to compare quality of banking service: a study of Turkish banks, The Business Review, Vol. 5,No. 1,pp.128-37.

Fairland, D. (1995), Can anyone get globalization right?, Institutional investor, Vol 29, No. 8, pp. 40-6

Farquhar, P.H. (1989), Managing brand equity, Marketing Research, Vol. 1 No. 3, pp. 24-33.

He, H. and Li, Y. (2011), Key service drivers for high-tech service brand equity: the mediating role of overall service quality and perceived value, Journal of Marketing Management, Vol. 27 No. 1, pp. 77-99.

Harris, G. (2002), Brand strategy in the retail banking sector: adapting to the financial services revolution, Brand Management, Vol. 9 No. 6, pp. 430-6.

Keller, K.L. (1993), Conceptualizing, measuring and managing customer-based brand equity, Journal of Marketing, Vol. 57 No. 1, pp. 1-22.

Kim, W.G. and Kim, H.B. (2004), Measuring customer based restaurant brand equity: investigating the relationship between brand equity and firm performance, Cornell hotel and restaurant administration Quarterly, Vol. 45 No. 2, pp. 115-31.

Kotler,P.(1991),Marketing Management, 7thed.,Prentice-Hall,Inc.,EnglewoodCliffs,NJ.

Levitt, T. (1981), Marketing intangible products and product intangibles, Harvard Business Review, Vol. 59 No. 3, pp. 94-102.

Deirdre O' Loughlin, Isabelle Szmigin, (2005), Customer perspectives on the role and importance of branding in Irish retail financial services, International Journal of Bank Marketing, Vol. 23 Iss: 1 , pp. $8-27$

Mahajan, V., Rao, V.R. and Srivastava, R.K. (1990),Development, testing, and validation of brand equity under conditions of acquisition and divestment, in Maltz, E. (Ed.),Managing Brand Equity: A Conference Summary Report, No. 91-110, Marketing Science Institute, Cambridge, MA,pp. 14-15.

Maio Mackay, M. (2001), Application of brand equity measures in service markets, Journal of Services Marketing, Vol. 15 No. 3, pp. 210-21.

Nellis, J.G., McCaffery, K.M. and Hutchinson, R.W. (2000), Strategic challenges for European banking industry in the new millennium, The International Journal of Bank Marketing, Vol. 18 No.2, pp. 53-64.

Palmer, A. (2001), Principles of Services Marketing, 3rd ed., McGraw-Hill, London.

Pinar, M. and Eser, Z., (2008), Examining the bank service quality from the personnel point of view : The comparison of state, private and foreign banks of Turkey, The Business Review, Vol. 10,No. 2,pp.27-33.

Pinar, M., Girard, T. and Eser, Z., (2012), Consumer based brand equity in banking industry: A comparison of local and global banks in Turkey, The International Journal of Bank Marketing, Vol. 30,No. 5,pp.359-375. 
Impact of Customer Based Brand Equity (CBBE) on Customer Retention: A comparative study of Government, Private and Foreign banks of Lahore, Pakistan

Pappu, R., Quester, G., P. and Cooksay, W., R. (2005), Consumer based brand equity in banking industry: A comparison of local and global banks in Turkey, Journal of Product and Brand management, 14/3, pp.143-154.

Park, C.S. and Srinivasan, V. (1994), A survey-basedmethod for measuring and understanding brand equity and its extendibility, Journal of Marketing Research, Vol. 31 No. 2, pp. 271-88.

Robinson, K. (2007), Retail banking: the pros and cons of global branding, The Banker, July, p.1

Rangaswamy, A., Burke, R. and Olive, T.A. (1993), Brandequity and the extendibility of brand names, International Journal of Research in Marketing, Vol. 10 No. 1, pp. 61-75.

Simon, C.J. and Sullivan, M.W. (1993), The measurementand determinants of brand equity: a financial approach,Marketing Science, Vol. 12 No. 1, pp. 28-52.

Yoo, B., Donthu, N. and Lee, S. (2000), An examination ofselected marketing mix elements and brand equity,Journal of the Academy of Marketing Science, Vol. 28 No. 2,pp. 195-211.

Yoo, B. and Donthu, N. (2001), Developing and validating amultidimensional consumer-based brand equity scale,Journal of Business Research, Vol. 52, pp. 1-14. 